\title{
The Signaling Mechanism of Contraction Induced by ATP and UTP in Feline Esophageal Smooth Muscle Cells
}

\author{
Tae Hoon Kwon', Hyunwoo Jung ${ }^{1}$, Eun Jeong Cho', Ji Hoon Jeong', and Uy Dong Sohn",*
}

\begin{abstract}
P2 receptors are membrane-bound receptors for extracelIular nucleotides such as ATP and UTP. P2 receptors have been classified as ligand-gated ion channels or P2X receptors and $G$ protein-coupled $P 2 Y$ receptors. Recently, purinergic signaling has begun to attract attention as a potential therapeutic target for a variety of diseases especially associated with gastroenterology. This study determined the ATP and UTP-induced receptor signaling mechanism in feline esophageal contraction. Contraction of dispersed feline esophageal smooth muscle cells was measured by scanning micrometry. Phosphorylation of $M L C_{20}$ was determined by western blot analysis. ATP and UTP elicited maximum esophageal contraction at $30 \mathrm{~s}$ and $10 \mu M$ concentration. Contraction of dispersed cells treated with $10 \mu M$ ATP was inhibited by nifedipine. However, contraction induced by $0.1 \mu$ M ATP, $0.1 \mu$ M UTP and $10 \mu M$ UTP was decreased by U73122, chelerythrine, ML-9, PTX and GDPBS. Contraction induced by $0.1 \mu M$ ATP and UTP was inhibited by $G_{\alpha i_{3}}$ or $G \alpha q$ antibodies and by $P L C \beta_{1}$ or $\mathrm{PLCB}_{3}$ antibodies. Phosphorylated $M L C_{20}$ was increased by ATP and UTP treatment. In conclusion, esophageal contraction induced by ATP and UTP was preferentially mediated by $P 2 Y$ receptors coupled to $\mathrm{G \alpha}_{3} i_{3}$ and $\mathrm{G} \alpha q$ proteins, which activate $P L C \beta_{1}$ and $P L C \beta_{3}$. Subsequently, increased intracellular $\mathrm{Ca}^{2+}$ and activated PKC triggered stimulation of MLC kinase and inhibition of MLC phosphatase. Finally, increased $p M L C_{20}$ generated esophageal contraction.
\end{abstract}

\section{INTRODUCTION}

The esophagus is a muscular tube that connects the back of the pharynx to the top of the stomach and ranges from approximately $18-25 \mathrm{~cm}$ in length, and $1-2 \mathrm{~cm}$ in diameter. The muscles in the upper portion of the esophagus, also called the up-

\footnotetext{
${ }^{1}$ Department of Pharmacology, College of Pharmacy, ${ }^{2}$ Department of Pharmacology, College of Medicine, Chung-Ang University, Seoul 156756, Korea

*Correspondence:udsohn@cau.ac.kr
}

Received 30 December, 2014; revised 7 April, 2015; accepted 16 April, 2015; published online 27 May, 2015

Keywords: ATP, contraction, Esophagus, P2Y receptor, UTP per esophageal sphincter (UES), are under voluntary control. The lower esophageal sphincter (LES) is a bundle of muscles at the low end of the esophagus, where it connects the stomach. When the LES is closed, it prevents acid and stomach content reflux. The LES consists of smooth muscle like the rest of the digestive tract. Smooth muscle in the gastrointestinal tract is controlled by the autonomic nervous system. Contraction or relaxation of smooth muscle has a key role in gastrointestinal motility. Digestive motility disorders can lead to impaired peristalsis resulting in slow contractions, rapid contractions, or combination of both slow and fast contractions (Vantrappen et al., 1986).

Recently, physiological and pharmacological investigation showed that neurotransmitters other than acetylcholine or noradrenaline are involved in peripheral autonomic transmission. These neurotransmitters are commonly referred to as nonadrenergic, non-cholinergic (NANC) neurotransmitters (Burnstock et al., 1997). Representative NANC neurotransmitters are composed of the peptide mediators including calcitonin generelated peptide (CGRP) and substance $P$, and the non-peptide mediators including nitric oxide (NO) and nucleotides such as ATP and UTP (Lundberg, 1996). The nucleotidesin the form of the nucleoside triphosphates ATP and UTP play important roles as essential energy sources and enzyme cofactors in cellular metabolism. Furthermore, ATP and UTP also function as extracellular messengers inducing intracellular signaling through activation of distinct cell surface receptors of the $\mathrm{P} 2$ receptor family (Ralevic and Burnstock, 1998).

The P2 receptors for extracellular nucleotides are ubiquitously distributed in various organs of the body and involved in regulation of almost all physiological processes such as the immune, inflammatory, cardiovascular, muscular, and central and peripheral nervous systems (Abbracchio et al., 2006; Surprenant and North, 2009). The term "P2" implies that purine and pyrimidine nucleotides can act as selective ligands of various receptor subtypes (Fredholmet al., 1997). The P2 receptors exist as 2 distinct families. P2X receptors are ligand-gated ionotropic channel family, gating primarily $\mathrm{Na}^{+}, \mathrm{K}^{+}, \mathrm{Cl}^{-}$and $\mathrm{Ca}^{2+}$. They are composed of 7 subtypes $\left(\mathrm{P}_{2} \mathrm{X}_{1}, \mathrm{P} 2 \mathrm{X}_{2}, \mathrm{P} 2 \mathrm{X}_{3}, \mathrm{P} 2 \mathrm{X}_{4}, \mathrm{P} 2 \mathrm{X}_{5}, \mathrm{P} 2 \mathrm{X}_{6}\right.$, and $P 2 X_{7}$ ) (Jiang et al., 2003). P2Y receptors are metabotropic, heptahelical G-protein coupled receptor (GPCR) family members with 8 identified subtypes: $\mathrm{P}_{2 Y_{1}}, \mathrm{P}_{2} \mathrm{Y}_{2}, \mathrm{P}_{2} \mathrm{Y}_{4}, \mathrm{P}_{2} \mathrm{Y}_{6}, \mathrm{P}_{2} \mathrm{Y}_{11}$, $\mathrm{P}_{2 Y_{12}}, \mathrm{P}_{2 Y_{13}}$, and P2Y ${ }_{14}$ (Abbracchio et al., 1997; Fredholm et al 1997; Lee et al., 2000). Recently, purinergic signaling has begun to attract attention as a potential therapeutic target for a 
variety of diseases (Burnstock, 2006). Exploratory studies focused on purinergic receptors as the future therapeutic targets of Gl diseases (Burnstock, 2008; Yiangou et al., 2001).

It was previously demonstrated that both $\mathrm{P} 2 \mathrm{X}$ and $\mathrm{P} 2 \mathrm{Y}$ receptors exist in esophageal smooth muscle and mediate esophageal contraction (Cho et al., 2010). However, the detailed signaling mechanism of ATP- and UTP- induced contraction via P2X and P2Y receptors in feline esophageal smooth muscle has not been studied. Understanding the signaling mechanism of purinergic receptors on esophagus can contribute to the treatment of esophageal diseases. In addition, coexistence of $\mathrm{P} 2 \mathrm{X}$ and $\mathrm{P} 2 \mathrm{Y}$ receptors raises the question of which receptor subtype preferentially mediates the action of the endogenous ligand. The purpose of this study was to investigate which receptor preferentially induces contraction activated by ATP and UTP and the signaling mechanism involved in feline esophageal smooth muscle cells. The nucleotides ATP and UTP were utilized to activate P2 receptors and to identify preferentially activated receptor and the signaling pathways. Selective G-protein antibody was utilized to identify the coupling of specific G-proteins to effector enzymes, and selective inhibitors were used to characterize the pathways involved in $\mathrm{MLC}_{20}(20$ $\mathrm{kDa}$, regulatory light chain of Myosin II) phosphorylation and esophageal smooth muscle cell contraction.

\section{MATERIALS AND METHODS}

\section{Materials and reagents}

$\mathrm{G}$ protein antibodies $\left(\mathrm{G}_{\alpha \mathrm{i} 1}, \mathrm{G}_{\alpha \mathrm{i} 2}, \mathrm{G}_{\alpha \mathrm{i} 3}, \mathrm{G}_{\alpha \mathrm{q}}, \mathrm{G}_{\alpha \mathrm{\alpha}}, \mathrm{G}_{\alpha \mathrm{o}}\right.$, and $\left.\mathrm{G}_{\beta}\right)$ and PLC antibodies $(\beta 1, \beta 3, \gamma 1)$ from Santa Cruz Biotechnology (USA); Chelerythrine chloride from Research Biochemicals (USA); goat anti-rabbit IgG-HRP from Bethyl Laboratories Inc. (USA); rainbow molecular weight marker from Amersham (USA); enhanced chemiluminescence (ECL) agents from PerkinElmer Life Sciences (USA); sodium dodecyl sulfate (SDS) sample buffer from Owl scientific Inc. (USA); nitrocellulose membrane, Tris/Glycine/SDS buffer and Tris/Glycine buffer from BioRad (USA); phosphate-buffered saline (PBS) from Roche Diagnostics Co. (USA); Restore ${ }^{\mathrm{TM}}$ Western Blot Stripping Buffer from Pierce (USA); and 4-(2-hydroxyethyl)-1piperazine-N'-2-ethane sulfonic acid (HEPES), collagenase type $\mathrm{F}$, ammonium persulfate, ponceau $\mathrm{S}$, bovine serum albumin (BSA), leupeptin, aprotinin, $\beta$-mercaptoethanol, $N, N, N^{\prime}, N^{\prime}-$ tetramethylethylene diamine (TEMED), ethylene glycol-bis-( $\beta$ aminoethylether)- $\mathrm{N}, \mathrm{N}, \mathrm{N}^{\prime}, \mathrm{N}^{\prime}$-tetraacetic acid (EGTA), ethylenediaminetetraacetic acid (EDTA), phenylmethyl-sulfonylfluoride (PMSF) and other reagents from Sigma Chemical Co. (USA).

\section{Tissue dissection and dispersion of smooth muscle cells}

Adult male cats weighing between 3 and $5 \mathrm{~kg}$ were anesthetized and esophageal smooth muscle tissue was prepared as previously described (Biancaniet al., 1987; Murthy and Makhlouf, 1998; Nam et al., 2013). The tissue was digested overnight maintaining a temperature of $4^{\circ} \mathrm{C}$ with HEPES-buffered solution thatcontained $1 \mathrm{mg} / \mathrm{ml}$ papain, $1 \mathrm{mM}$ dithiothreitol, $1 \mathrm{mg} / \mathrm{ml} \mathrm{BSA}$ and $0.5 \mathrm{mg} / \mathrm{ml}$ collagenase (type $\mathrm{F}$, Sigma). The HEPESbuffered solution contained $1 \mathrm{mM} \mathrm{CaCl}_{2}, 250 \mu \mathrm{M}$ EDTA, $10 \mathrm{mM}$ glucose, $10 \mathrm{mM}$ HEPES, $4 \mathrm{mM} \mathrm{KCl}, 131 \mathrm{mM} \mathrm{NaCl}, 1 \mathrm{mM}$ $\mathrm{MgCl}_{2}$ and $10 \mathrm{mM}$ taurine.

Next day, the tissue was warmed in HEPES-buffed solution at room temperature $\left(15-20^{\circ} \mathrm{C}\right)$ for $30 \mathrm{~min}$ and then heated in a water bath at $31^{\circ} \mathrm{C}$ for $30 \mathrm{~min}$. After heating, the digested tissue was poured out over a $400 \mu \mathrm{m}$ nylon mesh, rinsed in collagenase-free HEPES buffer to remove any trace of collagenase and then incubated in this solution at $31^{\circ} \mathrm{C}$, which was gassed with $95 \% \mathrm{O}_{2}-5 \% \mathrm{CO}_{2}$. The cells were allowed to dissociate freely for 10 to $20 \mathrm{~min}$. Before beginning the experiment, the cells were kept at $31^{\circ} \mathrm{C}$ for at least 10 min to relax the cells. Throughout the procedure, care was taken not to agitate the fluid in order to avoid cell contraction in response to mechanical stress.

The experiments were performed in accordance with the guidelines of the Institutional Animal Care and Use Committee of Chung-Ang University (No.14-0045).

\section{Preparation of permeabilized smooth muscle cells}

Cells were permeabilized, when required, to diffuse agents such as G protein antibodies and PLC isozyme antibodies, which do not diffuse across intact cell membrane. The process of preparation of permeabilized cells did not affect cell contraction (Cao et al., 2001; Horowitz et al., 1996; Murthy et al., 2003; Shim et al., 2002;Sohn et al., 1997). After completion of the enzymatic phase of the digestion process, the partly digested muscle tissue was washed with an enzyme-free cytosolic buffer of the following composition: $20 \mathrm{mM} \mathrm{NaCl}, 100 \mathrm{mM} \mathrm{KCl}, 5.0$ $\mathrm{mM} \mathrm{MgSO}{ }_{4} ; 0.96 \mathrm{mM} \mathrm{NaH}_{2} \mathrm{PO}_{4} ; 1.0 \mathrm{mM}$ EGTA and $0.48 \mathrm{mM}$ $\mathrm{CaCl}_{2}$ and $2 \%$ bovine serum albumin. The cytosolic buffer was equilibrated with $95 \% \mathrm{O}_{2}-5 \% \mathrm{CO}_{2}$ to maintain $\mathrm{pH} 7.2$ at $31^{\circ} \mathrm{C}$. The muscle cells were dispersed spontaneously in this medium. The cytosolic buffer contained $0.48 \mathrm{mM} \mathrm{CaCl}_{2}$ and $1 \mathrm{mM} \mathrm{EGTA}$, yielding $0.18 \mathrm{mM}$ free $\mathrm{Ca}^{2+}$ (Fabiato and Fabiato, 1979).

After dispersion, the cells were permeabilized by incubation for $5 \mathrm{~min}$ in cytosolic buffer containing saponin $(75 \mu \mathrm{g} / \mathrm{ml})$. After exposure to saponin, the cell suspension was spun at $350 \mathrm{~g}$, and the resulting pellet was washed with saponin-free modified cytosolic buffer that contained antimycin A $(10 \mu \mathrm{M})$, ATP $(1.5$ $\mathrm{mM}$ ) and an ATP-regenerating system that consisted of creatine phosphate $(5 \mathrm{mM})$ and creatine phosphokinase (10 units $/ \mathrm{ml}$ ) (Bitar et al., 1986). The procedure was repeated twice to ensure complete removal of saponin. After the cells were washed free of saponin, they were resuspended in modified cytosolic buffer.

\section{Measurement of contraction by scanning micrometry}

Contraction of isolated muscle cells was measured by scanning micrometry (Murthy and Makhlouf, 1998; Sohn et al., 1993; 1995b). An aliquot of cell suspension containing $10^{4}$ cells $/ \mathrm{ml}$ was added to HEPES medium containing the test agents. The reaction was terminated by addition of acrolein ( $1 \%$ final concentration). The length of 30 to 40 muscle cells treated with a contractile agent was measured at random by scanning micrometry, with a phase contrast microscope (ULWCD 0.30 Olympus,Japan) and digital closed-circuit video camera (CCD color camera, Japan) connected to a Macintosh computer (Apple, USA) with a software program, NIH Image 1.57 (National Institutes of Health, USA). It was then compared with length of untreated cells. Contraction was expressed as the percentage decrease of mean cell length, as compared with control group. All measurements were done in the presence of adenosine $A 1$ and A2 antagonists (1 mM DPCPX and $0.1 \mathrm{mM}$ CGS-15943, respectively) (Murthy et al., 1995).

\section{Protein assays}

The protein concentration of supernatant was determined by the Bradford reagents, according to the instruction of the manufacturer (Bio-Rad Chemical Division, USA). The absorbance was measured spectrophotometrically at a wavelength of $595 \mathrm{~nm}$. 

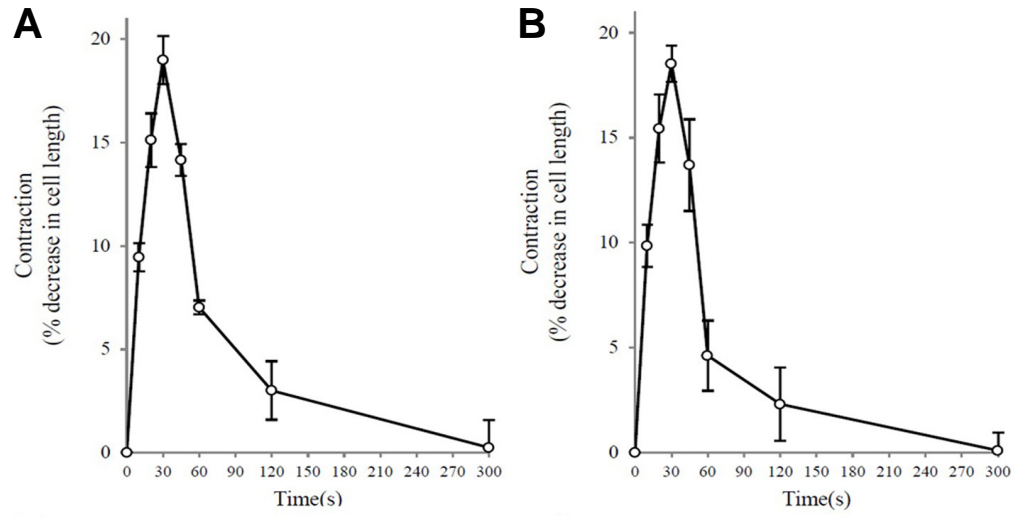

C

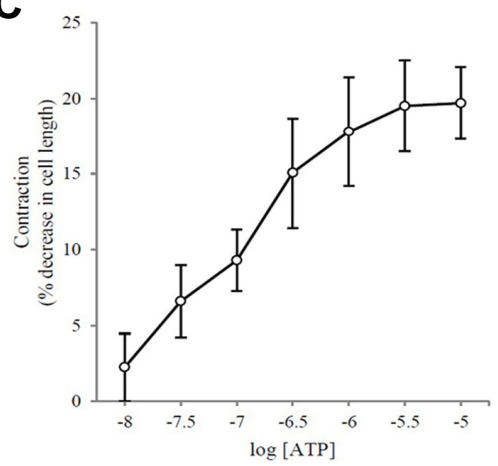

D

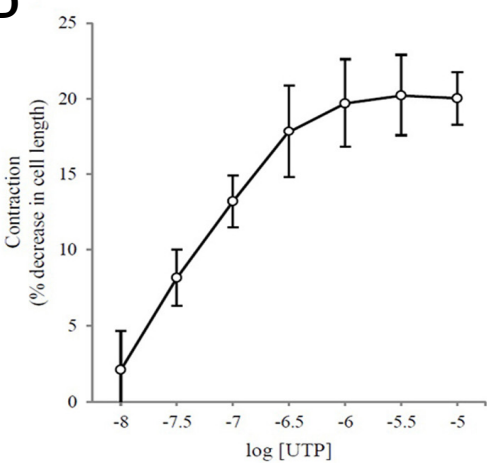

Fig. 1. Time course curves and concentrationresponse curves of contractile response induced by ATP and UTP in dispersed feline esophageal smooth muscle cells. (A) Time course curve of contraction in response to $1 \mu \mathrm{M}$ ATP. The response was detected at 10, 20,30, 45, 60, 120 and $300 \mathrm{~s}$. (B) Time course curve of contraction in response to $1 \mu \mathrm{M}$ UTP. (C) ATP-induced contraction of dispersed smooth muscle cells was measured at $30 \mathrm{~s}$ after treatment of ATP in different concentration $\left(10^{-8}, 10^{-7.5}, 10^{-7}, 10^{-6.5}, 10^{-6}, 10^{-}\right.$ 5.5, $\left.10^{-5} \mathrm{M}\right)$. (D) Concentration-response curve induced by UTP was measured at $30 \mathrm{~s}$ after ATP treatment at different concentrations $\left(10^{-8}\right.$ to $10^{-5}$ M). Muscle cell contraction was measured by scanning micrometry and expressed as percent decrease in cell length from control. Data are expressed as the mean \pm S.E.M $(n=5)$.

\section{Western blot analysis}

Dispersed muscle cells isolated from the esophagus were resuspended in DMEM, containing penicillin (100 unit/ml), streptomycin $(0.1 \mathrm{mg} / \mathrm{ml})$, amphotericin-b $(0.25 \mu \mathrm{g} / \mathrm{ml})$ and $10 \%$ fetal bovine serum (FBS). The muscle cells were plated at a concentration of $10^{4}$ cells $/ \mathrm{ml}$ and incubated at $37^{\circ} \mathrm{C}$ in a $\mathrm{CO}_{2}$ incubator. DMEM-10 medium was replaced every 3 days for 2-3 weeks until confluence was attained. All experiments were done on cells in the second passage (Murthy et al., 2003).

Phosphorylated $\mathrm{MLC}_{20}$ was determined by immunoblot analysis using a phospho-specific antibody (Huang et al., 2005; Murthy et al., 2003). Previously frozen samples of dispersed muscle cells were homogenized in a buffer containing $20 \mathrm{mM}$ Tris- $\mathrm{HCl}$ (pH 7.4), $0.5 \mathrm{mM}$ EDTA, $0.5 \mathrm{mM}$ EGTA, 1\% (w/v) Triton $\mathrm{X}-100,0.01 \%(\mathrm{w} / \mathrm{v})$ SDS, $10 \mu \mathrm{g} / \mathrm{ml}$ leupeptin, $10 \mu \mathrm{g} / \mathrm{ml}$ aprotinin, $1 \mathrm{mM}$ PMSF, phosphatase inhibitor cocktail-3 $10 \mu \mathrm{l} / \mathrm{ml}$ and $\beta$-mercaptoethanol $0.7 \mu \mathrm{g} / \mathrm{ml}$. Samples of the homogenates were then centrifuged for $10 \mathrm{~min}$ at $4^{\circ} \mathrm{C}$, and the supernatants collected. Equal amounts of proteins from each sample were resolved on an SDS- polyacrylamide gel by electrophoresis. Prestained molecular mass marker in loading buffer: 25 $\mathrm{mM}$ Tris (pH 8.3), $192 \mathrm{mM}$ glycine and 0.1\% SDS, was also run in an adjacent lane to permit molecular mass determination using a power supply (Power Pac 1000, Bio-Rad, USA). The separated proteins were transferred to $0.45 \mu \mathrm{m}$ nitrocellulose membrane in transfer buffer: $25 \mathrm{mM}$ Tris $(\mathrm{pH} 8.3), 192 \mathrm{mM}$ glycine and $20 \%$ (v/v) methanol, using a power supply (Power Pac 1000, Bio-Rad, USA). To confirm uniformity of gel loading, blots were stained with Ponceau S. After confirmation, the membrane was washed with TBS, and then the membrane was incubated in TBS buffer containing 3\% BSA and $0.05 \%$ Tween20 (TBST) for $3 \mathrm{~h}$ at room temperature to block nonspecific binding. After washing thrice for $15 \mathrm{~min}$ with TBS, the membrane was incubated with antibodies (1:1,000 dilution) to
$\mathrm{pMLC}_{20}$ (Ser19/Thr18) in a TBST solution containing 3\% BSA at $4^{\circ} \mathrm{C}$ overnight. Then the membrane was washed twice for 5 min using TBST and incubated with horseradish peroxidaseconjugated secondary antibody (1:5,000 dilution) for $1 \mathrm{~h}$ at room temperature. The immunoreactive bands, detected by enhanced chemiluminescence agents (ECL, Perkin Elmer, USA), were developed by $\mathrm{X}$-ray film developer and fixer. Developed films from ECL were scanned and analyzed densitometrically using Scion Image. Phosphorylation of $\mathrm{MLC}_{20}$ was calculated as the ratio of phosphorylated $\mathrm{MLC}_{20}$ to total MLC $_{20}$ (Cao et al., 2001; ljzeret al., 2009; Nam et al., 2013). All measurements were done in the presence of adenosine $A 1$ and A2 antagonists (1 mM DPCPX and $0.1 \mathrm{mM}$ CGS-15943, respectively) (Murthyet al., 1995).

\section{Analysis of data}

The results were expressed as mean + or \pm S.E.M. of $n$ experiments. $P$ values were determined by one-way ANOVA with post-hoc Tukey HSD (Honest Significant Differences) using GraphPad PRISM (GraphPad Software, USA). Each experiment was done on cells obtained from different animals. Values were considered statistically significant when $P$ value $<0.05$.

\section{RESULTS}

Contraction induced by ATP and UTP in dispersed smooth muscle cells

Dispersed feline esophageal smooth muscle cells were treated for $10,20,30,45,60,120$, and $300 \mathrm{~s}$ with $1 \mu \mathrm{M}$ ATP or UTP. Exposure of dispersed smooth muscle cells to $1 \mu \mathrm{M}$ ATP caused immediate contraction that significantly increased until $30 \mathrm{~s}$. Maximal contraction was attained at $30 \mathrm{~s}$ followed by a decline to lower levels. The contraction almost disappeared after 5 min (Fig. 1A). 


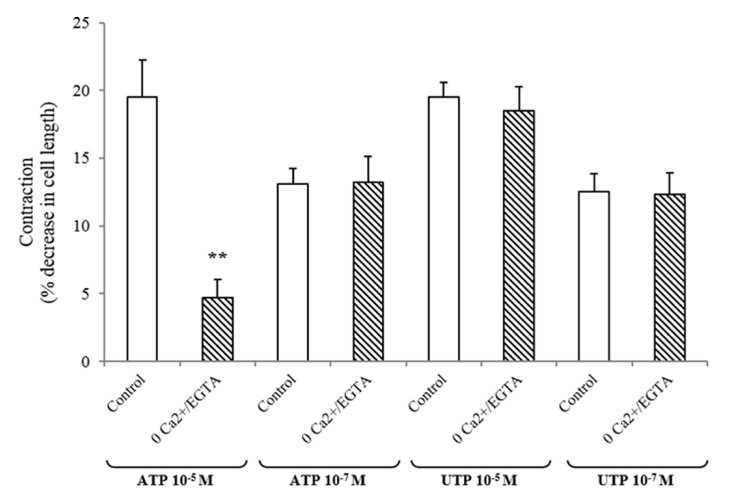

Fig. 2. Inhibition of ATP- and UTP-induced contraction in dispersed feline esophageal smooth muscle cells in the absence of $\mathrm{Ca}^{2+}$ from the medium $\left(0 \mathrm{Ca}^{2+} / 2 \mathrm{mM}\right.$ EGTA). Dispersed smooth muscle cells were preincubated in $\mathrm{Ca}^{2+}$-free medium and then treated with 10 $\mu \mathrm{M}$ ATP, $0.1 \mu \mathrm{M}$ ATP, $10 \mu \mathrm{M}$ UTP, and $0.1 \mu \mathrm{M}$ UTP for $30 \mathrm{~s}$. Muscle contraction was measured by scanning micrometry. Data are expressed as means + S.E.M $(n=4) .{ }^{\star \star} P<0.01$ versus control.

The time course was identical to that observed with $1 \mu \mathrm{M}$ UTP (Fig. 1B). The maximal response at $30 \mathrm{~s}$ was used in concentration-response curves. Contraction of dispersed feline smooth muscle cells were measured at $30 \mathrm{~s}$ after treatment of $10^{-8}, 10^{-7.5}, 10^{-7}, 10^{-6.5}, 10^{-6}, 10^{-5.5}, 10^{-5} \mathrm{M}$ ATP or UTP respectively. Treatment of ATP caused concentration-dependent contraction of dispersed feline esophageal smooth muscle cells. Each concentration of ATP was treated for a $30 \mathrm{~s}$ duration. The maximal peak was attained by $10 \mu \mathrm{M}$ concentration of ATP (Fig. 1C). The concentration-response curve showed the same pattern to that observed with treatment of UTP (Fig. 1D).

In calcium-free medium, contraction induced by $10^{-5} \mathrm{M}$ ATP was inhibited but contraction induced by ATP $10^{-7} \mathrm{M}$ or UTP was not inhibited. This result supported that contraction induced by $10^{-7} \mathrm{M}$ ATP or UTP was activated by intracellular $\mathrm{IP}_{3}$ pathway although contraction induced by $10^{-5} \mathrm{M}$ ATP depends on extracellular calcium ion (Fig. 2).

The signaling of contraction induced by ATP was altered depending on its concentration

P2X receptors are ligand-gated ionotropic channel family, especially $\mathrm{Ca}^{2+}$ channel, and $\mathrm{P} 2 \mathrm{Y}$ receptors are involved in pertussis toxin-sensitive and -insensitive $G$ proteins thatregulate diverse enzymes (Akbar et al., 1996; Chang et al., 1995; Cowen et al., 1990; Dubyak and el-Moatassim, 1993; Harden et al., 1995; Lazarowski and Harden, 1994).

Dispersed smooth muscle cells were pretreated with $\mathrm{Ca}^{2+}$ channel blocker nifedipine $1 \mu \mathrm{M}$ for 10 min or with pertussis toxin PTX $400 \mathrm{ng} / \mathrm{ml}$ and GDPßS $10 \mu \mathrm{M}$ for $1 \mathrm{~h}$ respectively, and then treated with $10 \mu \mathrm{M}$ or $0.1 \mu \mathrm{M}$ ATP and UTP for $30 \mathrm{~s}$. Contraction induced by $10 \mu \mathrm{M}$ ATP were abolished by only the $\mathrm{Ca}^{2+}$ channel blocker, nifedipine but were not affected by pretreatment of dispersed cells with PTX, and GDP $\beta S$ (Fig. 3A). In contrast, contraction induced by $0.1 \mu \mathrm{M}$ ATP wasinhibited by PTX or GDP $\beta S$ but not affected by nifedipine (Fig. 3B). Contractions induced by $10 \mu \mathrm{M}$ and $0.1 \mu \mathrm{M}$ UTP were abolished by PTX, and GDP $\beta S$ but were not affected by pretreatment of dispersed cells with nifedipine (Figs. $3 \mathrm{C}$ and $\mathrm{BD}$ ). The signaling of contraction induced by ATP was concentration-dependent. Higher concentration of ATP mediated contraction via P2X receptors. In contrast, lower concentration of ATP mediated contraction via P2Y receptors in accordance with UTP-induced contraction.

\section{Identification of the G protein subtypes related to ATP- and} UTP-induced contraction

The above experiment revealed that preferential signaling of ATP- and UTP-induced contraction was mediated by P2Y receptors. A previous study showed that ${\mathrm{G} \alpha i_{1}}_{1}, \mathrm{G}_{\alpha} \mathrm{i}_{2}, \mathrm{G} \alpha \mathrm{i}_{3}, \mathrm{G} \beta$ (40 $\mathrm{kDa}), \mathrm{G} \alpha \mathrm{o}(40 \mathrm{kDa}), \mathrm{G} \alpha \mathrm{q}(42 \mathrm{kDa})$, and $\mathrm{G} \alpha \mathrm{s}$ (46 kDa) proteins are expressedin cat smooth muscle cells (Yang et al., 2000).
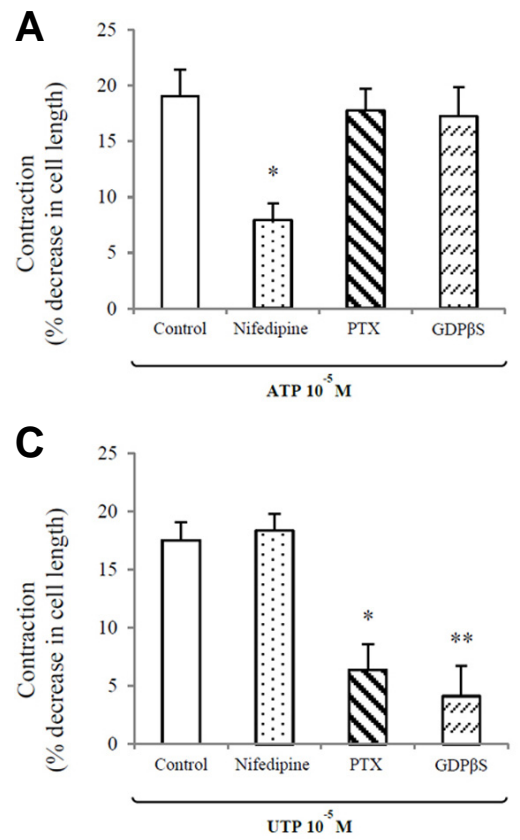

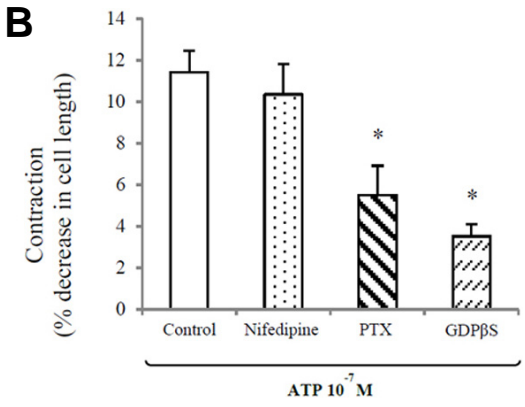

D

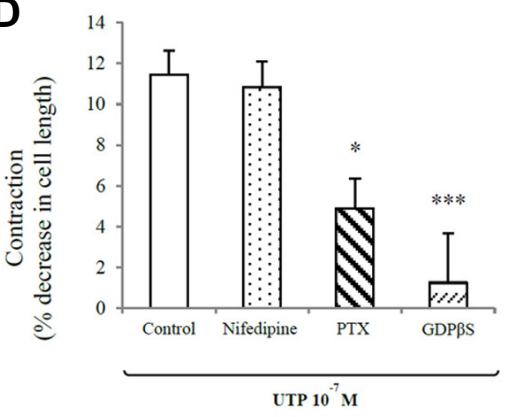

Fig. 3. Inhibition of ATP- and UTP-induced contraction in dispersed feline esophageal smooth muscle cells by nifedipine, pertussis toxin (PTX) and guanosine- 5 '-( $\beta$-thio)-diphosphate (GDPßS) Dispersed smooth muscle cells were preincubated with nifedipine $(1 \mu \mathrm{M})$ for $10 \mathrm{~min}$, PTX $(400 \mathrm{ng} / \mathrm{ml})$ and GDP $\beta S(10 \mu \mathrm{M})$ for $1 \mathrm{~h}$ respectively, and then treated with A) $10 \mu \mathrm{M}$ ATP, B) $0.1 \mu \mathrm{M}$ ATP, C) $10 \mu \mathrm{M}$ UTP, and D) $0.1 \mu \mathrm{M}$ UTP for $30 \mathrm{~s}$. Muscle contraction was measured by scanning micrometry. Data are expressed as the mean + S.E.M $(\mathrm{n}=5)$. ${ }^{*} P<$ $0.05,{ }^{\star *} P<0.01,{ }^{\star * \star} P<0.001$ versus control. 

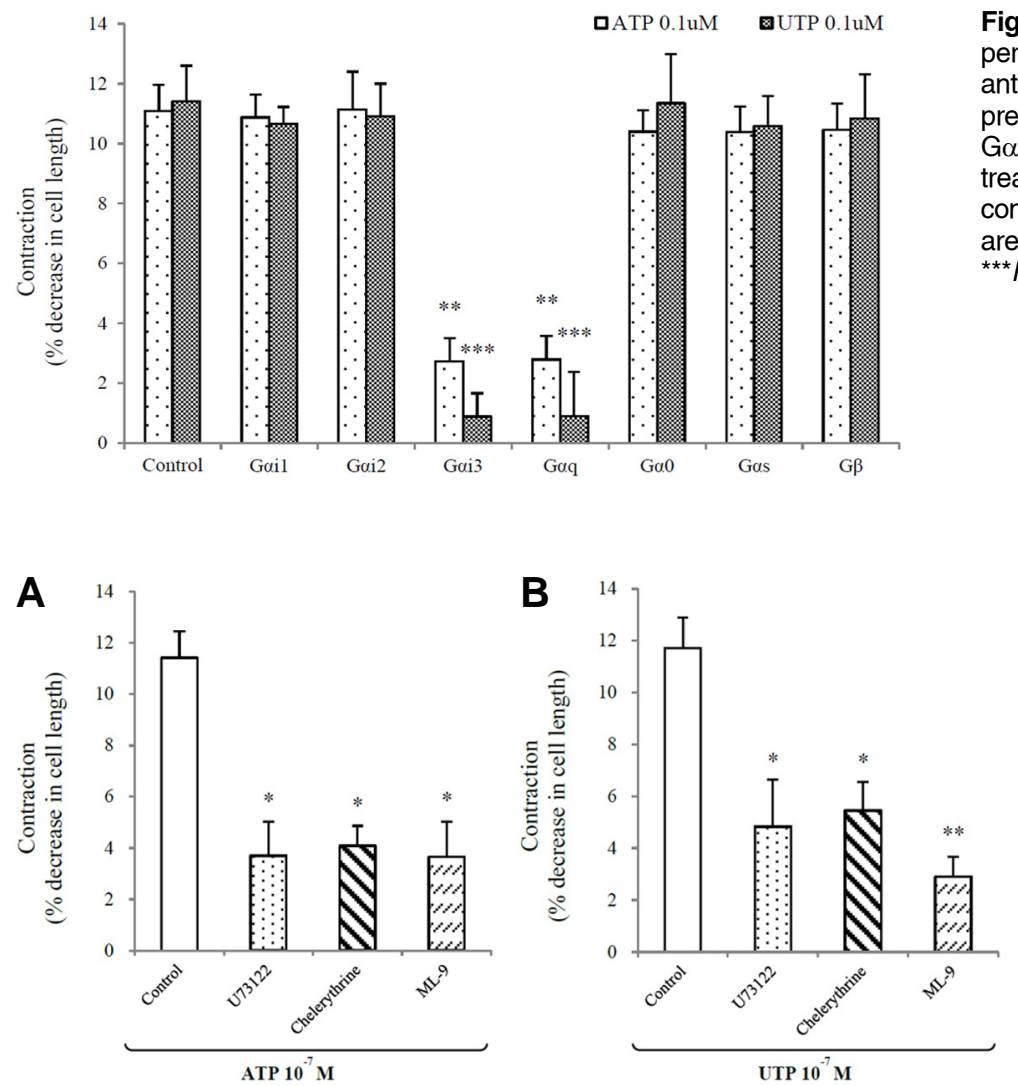

Fig. 4. Inhibition of ATP- and UTP- induced contraction in permeabilized feline esophageal smooth muscle cells by antibodies to $G$ protein isoforms. Permeabilized cells were preincubated with antibodies to Goi1, Gai2, Gai3, Gaq, $\mathrm{G} \alpha \mathrm{O}, \mathrm{G} \alpha \mathrm{s}$, and $\mathrm{G} \beta(1: 200)$ for $1 \mathrm{~h}$ respectively, and then treated with $0.1 \mu \mathrm{M}$ ATP or $0.1 \alpha \mathrm{M}$ UTP for $30 \mathrm{~s}$. Muscle contraction was measured by scanning micrometry. Data are expressed as the mean + S.E.M $(n=4) .{ }^{\star \star} P<0.01$, ${ }^{\star \star *} P<0.001$ versus control.
The subtypes of $G$ proteins activated by ATP and UTP in smooth muscle were identified by contractile blockade with $G$ protein-specific antibodies. Permeabilized feline esophageal smooth muscle cells were preincubated with specific antibodies to $\mathrm{G} \alpha i_{1}, \mathrm{G}_{\alpha} \mathrm{i}_{2}, \mathrm{G} \alpha \mathrm{i}_{3}, \mathrm{G} \alpha \mathrm{q}, \mathrm{G} \alpha \mathrm{O}, \mathrm{G} \alpha \mathrm{s}$, and $\mathrm{G} \beta$ for $1 \mathrm{~h}$ respectively, and then treated with $0.1 \mu \mathrm{M}$ ATP or $0.1 \mu \mathrm{M}$ UTP for $30 \mathrm{~s}$. Contraction induced by $0.1 \mu \mathrm{M}$ ATP was partially abolished by $\mathrm{G}_{\alpha} \mathrm{i}_{3}$ and G $\beta$. Treatment of $0.1 \mu \mathrm{M}$ UTP also produced the same results as treatment of $0.1 \mu \mathrm{M}$ ATP (Fig. 4).

The signaling pathway of contraction activated by ATP and UTP P2Y receptors involve diverse enzymes including phospholipase C (Akbar et al.,1996; Dubyak and el-Moatassim, 1993; Harden et al., 1995; Lazarowski and Harden, 1994), and protein kinase C (van der Weydenet al., 2000), which can induce activation of MLC kinase and inhibition of MLC phosphatase (Ikebeet al., 1987). Dispersed smooth muscle cells were pretreated with PLC inhibitor (U73122) $1 \mu \mathrm{M}$, PKC inhibitor (chelerythrine) $10 \mu \mathrm{M}$, or MLC kinase inhibitor (ML-9) $10 \mu \mathrm{M}$ for $10 \mathrm{~min}$, respectively, and then treated with $0.1 \mu \mathrm{M}$ ATP or UTP for $30 \mathrm{~s}$. Contraction induced by $0.1 \mu \mathrm{M}$ ATP and UTP were partially abolished by U73122, chelerythrine, and ML-9 (Figs. $5 \mathrm{~A}$ and $5 \mathrm{~B}$ ). The results suggested that the contraction mediated by P2Y receptors involved PLC, PKC, and MLC kinase.

Identification of the PLC isozymes involved in ATP- and UTP-induced contraction

It was found that contraction mediated by P2Y receptors was related to phosphoslipase C. Previous study in our laboratory demonstrated the presence of immunoreactive bands of 150
kDa with PLC $\beta_{1}$ and PLC $\beta_{3}$ antibodies, and $145 \mathrm{kDa}$ band with PLC $\gamma_{1}$ antibody in dispersed feline smooth muscle cells (Yang et al., 2000). The inhibitory effect of PLC isoform specific antibodies to ATP- and UTP-induced contraction was examined to determine which PLC isoforms mediated contraction. After preincubation of permeabilized smooth muscle cells for $1 \mathrm{~h}$ with PLC isozymes specific antibodies (1:200), dispersed cells were treated with $0.1 \mu \mathrm{M}$ ATP and UTP for $30 \mathrm{~s}$. PLC $\beta_{1}$ or PLC $\beta_{3}$ specific antibodies inhibited ATP-induced contraction. On the contrary, PLC $\gamma_{1}$ specific antibody did not have a significant inhibitory effect on contraction (Fig. 6A). UTP-induced contraction was also decreased by pretreatment with PLC $\beta_{1}$ or PLC $\beta_{3}$ specific antibodies (Fig. 6B).

\section{ATP- and UTP-induced phosphorylation of MLC $C_{20}$}

The primary mechanism of smooth muscle contraction is phosphorylation of the $20 \mathrm{kDa}$ myosin light chain $\left(\mathrm{MLC}_{20}\right)$. (Ikebe et al., 1987; Puetz et al., 2009; Webb, 2003). To verify that phosphorylation of $\mathrm{MLC}_{20}$ is related in esophageal contraction, Western blot analysis was performed to measure phosphorylated $\mathrm{MLC}_{20}\left(\mathrm{pMLC}_{20}\right)$ and total $\mathrm{MLC}_{20}\left(\mathrm{tMLC}_{20}\right)$ using specific antibodies to $\mathrm{pMLC}_{20}$ and $\mathrm{IMLC}_{20}$, respectively. Phosphorylation of $\mathrm{pMLC}_{20}$ was significantly increased in cultured cells treated with ATP and UTP, as comparedto control (Fig. 7). The results suggested that both ATP and UTP mediate contraction of feline esophageal smooth muscle via phosphorylation of $\mathrm{MLC}_{20}$.

\section{DISCUSSION}

A variety of signaling mechanisms are involved in contraction or 

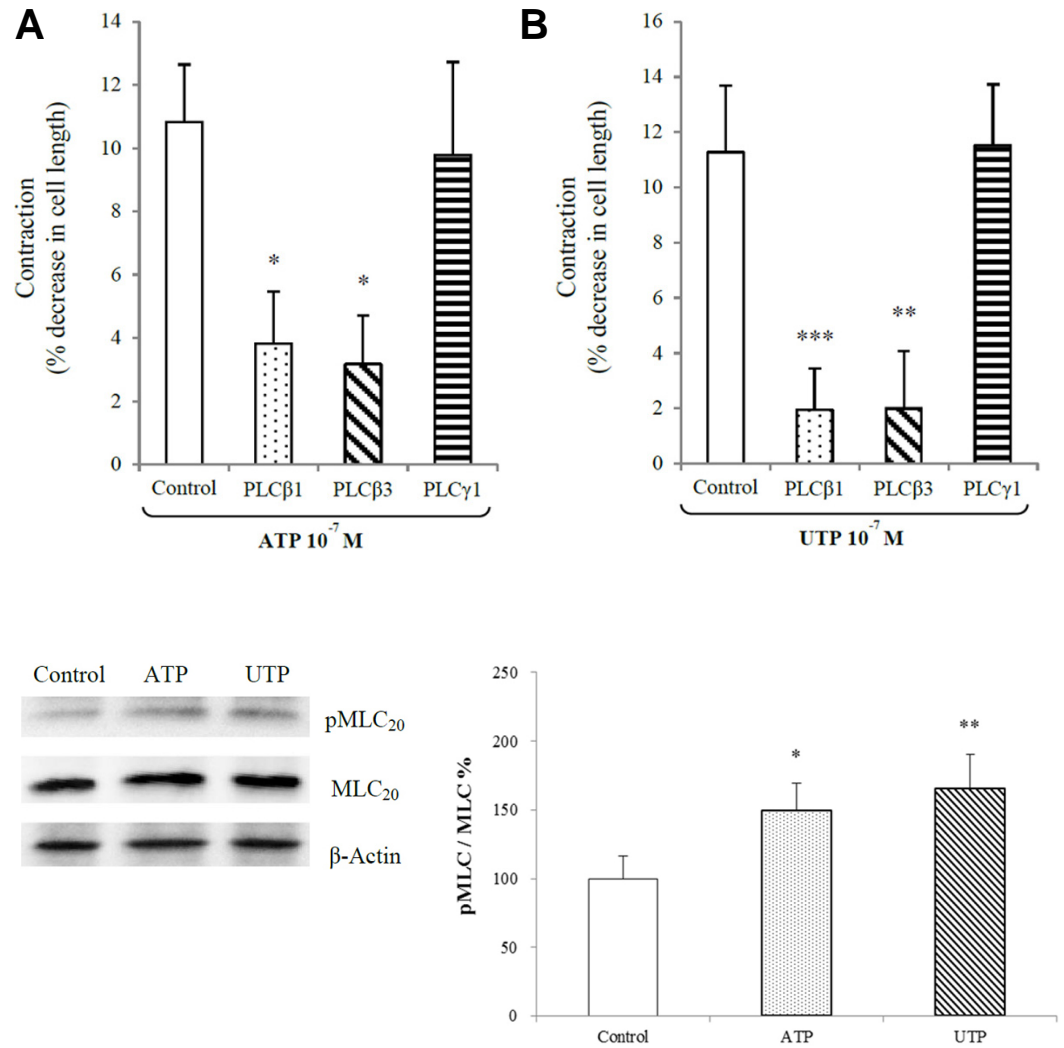

Fig. 7. ATP- and UTP- induced Contraction was mediated by $\mathrm{MLC}_{20}$ phosphorylation. Experiments were done on primary cultures of feline smooth muscle cells. Cultured cells were incubated with $0.1 \mu \mathrm{M}$ ATP or $0.1 \mu \mathrm{M}$ UTP, respectively. The 20 kDa-myosin light chain phosphorylation was confirmed by Western blot analysis using phosphorylated $\mathrm{MLC}_{20}$ (Ser19/ Thr18) antibody and $\mathrm{MLC}_{20}$ antibodies. Data were expressed as percent increase + S.E.M compared with control (n $=6) .{ }^{\star} P<0.05,{ }^{\star \star} P<0.01$ versus control. relaxation of esophageal smooth muscle. However, the detailed signaling mechanism of contraction induced by $\mathrm{P} 2$ receptors in esophageal smooth muscle has not been studied. It was reported that the NANC neurotransmitters play a key role in the diseased condition of GI tract (Lefebvre, 1993; Matsuda and Miller, 2010). Investigation of the NANC nucleotide ATP- and UTP-induced signaling mechanism of esophageal smooth muscle contraction contributes to understanding pathophysiology of esophageal diseases.

In the present study, we found that contraction induced by 10 $\mu \mathrm{M}$ ATP was mediated by P2X receptors that can induce influx of $\mathrm{Ca}^{2+}$ from extracellular space. In contrast, contraction induced by $0.1 \mu \mathrm{M}$ ATP was triggered by P2Y receptors linked to

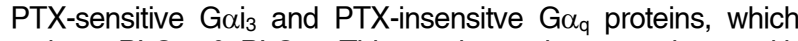
activate $P L C \beta_{1} \& P L C \beta_{3}$. This result was in concordance with the hypothesis that P2Y receptors preferentially induce esophageal smooth muscle contraction in response to ATP.

These conclusions derive from the following findings:

\section{ATP preferentially activated $P 2 Y$ receptors to elicit smooth muscle contraction}

$\mathrm{P} 2$ receptors have been classified into 2classes comprising P2X and P2Y receptors (Fredholm et al., 1994; 1997). P2X receptors are ligand-gated ionotropic channel family members that can induce transfer of calcium ion from extracellular space to cytoplasm (Fredholm et al., 1994; 1997). P2Y receptors are G-protein coupled receptor (GPCR) family that activate phospholipase C (PLC) (Fredholm et al., 1994; 1997; Lee et al., 2000). Previous study demonstrated that the co-existence of ligand-gated $P 2 X$ and $G$ protein-coupled $P 2 Y$ receptors in freshly dispersed gastric smooth muscle cells and that ATP preferentially activates $\mathrm{P} 2 \mathrm{Y}$ receptors to elicit $\mathrm{Ca}^{2+}$ mobilization and muscle contraction (Murthy and Makhlouf, 1998). Contraction induced by $10 \mu \mathrm{M}$ ATP was abolished by only the $\mathrm{Ca}^{2+}$ channel blocker, nifedipinethat can inhibit P2X receptor (Murthy and Makhlouf, 1998). P2Y receptors trigger release of $\mathrm{Ca}^{2+}$ from endoplasmic reticulum that leads to increase of calcium concentration. From our findings intracellular calcium concentration plays a key role in smooth muscle contraction induced by $\mathrm{P} 2$ receptors. It seems that contraction was not inhibited by Gai antibody because increase of calcium concentration induced by $\mathrm{P} 2 \mathrm{Y}$ receptors is negligible compared to that of $\mathrm{P} 2 \mathrm{X}$ receptors when treated with high concentration of ATP. In contrast, contraction induced by $0.1 \mu \mathrm{M}$ ATP, $10 \mu \mathrm{M}$ UTP and 0.1 $\mu \mathrm{M}$ UTP wasinhibited by PTX or GDP $\beta$ S.

The ATP-induced contraction signaling was concentrationdependent. Response to UTP and lower concentration of ATP was mediated by PTX-sensitive $G$ protein and PTX-insensitive $G$ protein but contraction induced by higher concentration of ATP occurred via ligand-gated calcium channel. Therefore, these results suggested that the purine nucleotide, ATP released from nerves as extracellular transmitters preferentially activate P2Y receptors to elicit smooth muscle contraction.

\section{$P 2 Y$ receptors were linked to $\mathrm{Gali}_{3}$ and Gaq proteins} activating $P L C \beta_{1}$ and $P L C \beta_{3}$

$G$ proteins, also known as guanine nucleotide-binding proteins, are a family of proteins involved in transmitting signals from a variety of intracellular signaling such as activation of PLC $\beta$ that can cleave $\mathrm{PIP}_{2}$ into $\mathrm{IP}_{3}$ and DAG (Gilman, 1987; Lechleiter et al., 1990; Somlyo and Somlyo, 1994). Contraction mediated by $\mathrm{P} 2 \mathrm{Y}$ receptors was decreased by $\mathrm{G} \alpha \mathrm{i}_{3}$ and $\mathrm{G} \alpha \mathrm{q}$ specific anti- 


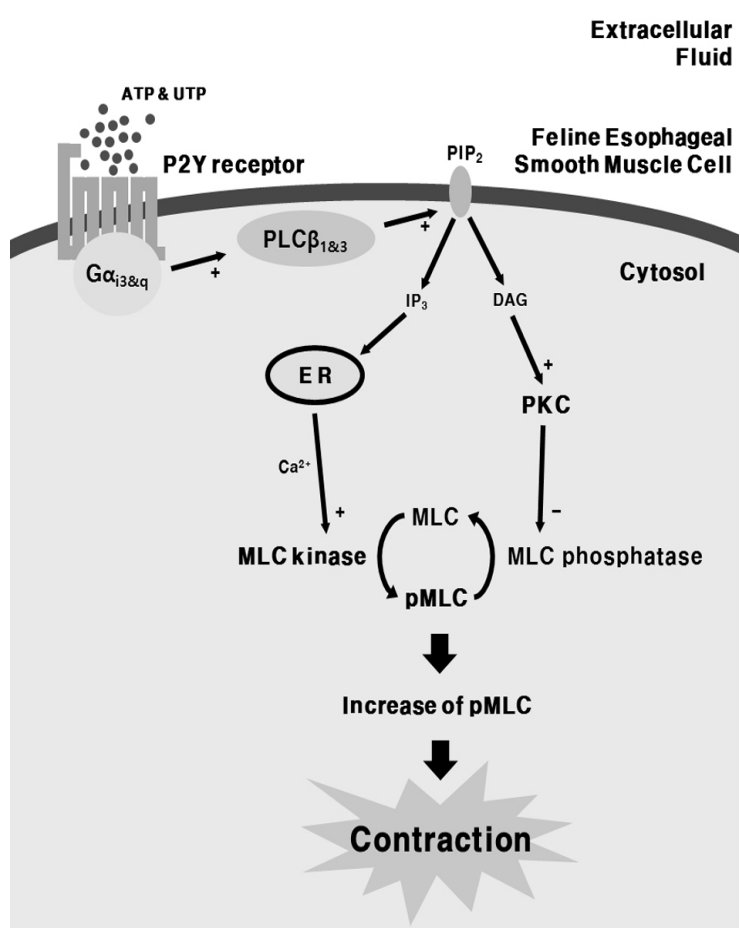

Fig. 8. Diagram of the preferential signaling mechanism mediated by ATP and UTP in feline esophageal smooth muscle cells. ATPinduced contraction of feline esophageal smooth muscle cells was preferentially mediated by $\mathrm{P} 2 \mathrm{Y}$ receptors coupled to $\mathrm{Ga}_{\mathrm{a}_{3}}$ and $\mathrm{G} \alpha_{q}$ proteins, which activate $P L C \beta_{1}$ and $P L C \beta_{3}$. Subsequent, increased intracellular $\mathrm{Ca}^{2+}$ by $\mathrm{IP}_{3}$ and activated PKC by DAG triggered stimulation of MLC kinase and inhibition of MLC phosphatase, respectively. Finally, increased $\mathrm{pMLC}_{20}$ generated smooth muscle contraction of the feline esophagus.

bodies and by PLC $\beta_{1}$ and PLC $\beta_{3}$ antibodies. Thus, P2Y receptors are involved in $\mathrm{G} \mathrm{i}_{3}$ and $\mathrm{G} \alpha \mathrm{q}$ proteins triggering activation of $P L C \beta_{1}$ and $P L C \beta_{3}$.

\section{Contraction mediated by $P 2 Y$ receptors was involved in} $I P_{3}$-dependent and PKC-dependent pathway

PLC catalysesthegeneration ofinositol triphosphate $\left(\mathrm{IP}_{3}\right)$ and diacylglycerol (DAG). $I P_{3}$ then binds to $\mathrm{IP}_{3}$ receptors, particularly $\mathrm{Ca}^{2+}$ channels in the smooth endoplasmic reticulum (ER). This induces increased cytoplasmic concentration of $\mathrm{Ca}^{2+}$, causing a cascade of intracellular changes and the activation of calmodulin and MLC kinase (MLCK)-dependent phosphorylation of MLC $_{20}$ (Billah and Anthes, 1990; Sohn et al., 1993; 1995a; Somlyo and Somlyo, 1994). DAG functions as a membrane bound second messenger signaling lipid. In addition, calcium and DAG together activate protein kinase $C$ (PKC), which phosphorylates other molecules, leading to altered cellular activity such as regulating myosin light chain phosphatase (MLCP) that can dephosphorylate pMLC (Puetz et al., 2009).

Contraction in response to $0.1 \mu \mathrm{M}$ ATP, $0.1 \mu \mathrm{M}$ UTP, and 10 $\mu \mathrm{M}$ UTP, but not $10 \mu \mathrm{M}$ ATP,was significantly inhibited by PLC inhibitor U73122, PKC inhibitor chelerythrine, and MLC kinase inhibitor ML-9. The results showed that $\mathrm{P} 2 \mathrm{Y}$ receptors mediate esophageal smooth muscle contraction through the $\mathrm{IP}_{3}$-dependent and PKC-dependent pathways.
P2Y receptors triggered contraction by $M L C_{20}$ phosphorylation

The primary mechanism of smooth muscle contraction is phosphorylation of the $20 \mathrm{kDa}$ myosin light chain $\left(\mathrm{MLC}_{20}\right)$ by a $\mathrm{MLC}_{20}$ kinase that is activated by Ca-calmodulin (lkebeet al., 1987). Relaxation, then, is primarily the result of dephosphorylation of $\mathrm{MLC}_{20}$ by MLC phosphatases (Bialojan et al., 1987; Haeberle et al., 1985). Phosphorylation of MLC $_{20}$ was increased by activating P2Y receptors. Our results demonstrated that P2Y receptors modulate smooth muscle contraction through myosin light chain phosphorylation, caused by the $\mathrm{IP}_{3-}$ dependent and PKC-dependent pathways.

In conclusion, ATP- and UTP-induced contraction of feline esophageal smooth muscle cells was preferentially mediated by P2Y receptors coupled to $\mathrm{G}_{\alpha} \mathrm{i}_{3}$ and $\mathrm{G} \alpha_{q}$ proteins, which activate $P L C \beta_{1}$ and $P L C \beta_{3}$. Subsequently, increased intracellular $\mathrm{Ca}^{2+}$ by $\mathrm{IP}_{3}$ and activated PKC by DAG triggered stimulation of MLC kinase and inhibition of MLC phosphatase, respectively. Finally, increased $\mathrm{pMLC}_{20}$ generated smooth muscle contraction of the feline esophagus (Fig. 8).

In time course ATP- and UTP-induced contraction curves, the contraction completely disappeared $300 \mathrm{~s}$ after ATP and UTP treatment. This pattern was different from other neurotransmitters that induce sustained contraction. It can be hypothesized that $\mathrm{P} 2$ receptor activation is associated with lower esophageal sphincter (LES) relaxation induced by GERD or other esophageal diseases. Further research is required to investigate P2 receptor induced-signaling of contraction in esophageal smooth muscle under pathophysiologicalor diseased conditions.

In summary (Fig. 8), esophageal contraction induced by ATP and UTP was preferentially mediated by $\mathrm{P} 2 \mathrm{Y}$ receptors coupled to $\mathrm{G \alpha i}_{3}$ and $\mathrm{G} \alpha \mathrm{q}$ proteins, which activate $\mathrm{PLC} \beta_{1}$ and $\mathrm{PLC} \beta_{3}$. Subsequently, increased intracellular $\mathrm{Ca}^{2+}$ and activated PKC triggered stimulation of MLC kinase and inhibition of MLC phosphatase, and increased $\mathrm{pMLC}_{20}$ generated esophageal contraction.

\section{ACKNOWLEDGMENTS}

This research was supported by the Basic Science Research Program through the National Research Foundation of Korea (NRF) funded by the Ministry of Education, Science and Technology (No. 2011-0012139), and by the Chung-Ang University Excellent Student Scholarship in 2014-2015.

\section{REFERENCES}

Abbracchio, M.P., Burnstock, G., Boeynaems, J.M., Barnard, E.A., Boyer, J.L., Kennedy, C., Knight, G.E., Fumagalli, M., Gachet, C., Jacobson, K.A., et al. (2006). International union of pharmacology LVIII: Update on the P2Y G protein-coupled nucleotide receptors: From molecular mechanisms and pathophysiology to therapy. Pharmacol. Rev. 58, 281-341.

Akbar, G.K., Dasari, V.R., Webb, T.E., Ayyanathan, K., Pillarisetti, K., Sandhu, A.K., Athwal, R.S., Daniel, J.L., Ashby, B., Barnard, E.A et al. (1996). Molecular cloning of a novel P2 purinoceptor from human erythroleukemia cells. J. Biol. Chem. 271, 18363-18367.

Bialojan, C., Rüegg, J.C., and DiSalvo, J. (1987). A myosin phosphatase modulates contractility in skinned smooth muscle. Pflugers Arch. 410, 304-312.

Biancani, P., Hillemeier, C., Bitar, K.N., and Makhlouf, G.M. (1987). Contraction mediated by $\mathrm{Ca}^{2+}$ influx in esophageal muscle and by $\mathrm{Ca}^{2+}$ release in the LES. Am. J. Physiol. 253, G760-766.

Billah, M.M., and Anthes, J.C. (1990). The regulation and cellular functions of phosphatidylcholine hydrolysis. Biochem J. 269, 281-291.

Bitar, K.N., Bradford, P.G., Putney, J.W., Jr., and Makhlouf, G.M. (1986). Stoichiometry of contraction and $\mathrm{Ca}^{2+}$ mobilization by inositol 1,4,5-trisphosphate in isolated gastric smooth muscle cells. J. Biol. Chem. 261, 16591-16596. 
Burnstock, G. (2006). Pathophysiology and therapeutic potential of purinergic signaling. Pharmacol. Rev. 58, 58-86.

Burnstock, G. (2008). Purinergic receptors as future targets for treatment of functional GI disorders. Gut 57, 1193-1194.

Burnstock, G., Campbell, G., Satchell, D., and Smythe, A. (1997). Evidence that adenosine triphosphate or a related nucleotide is the transmitter substance released by nonadrenergic inhibitory nerves in the gut (Reprinted from Brit J Pharmacol, vol 40, pp 668-688, 1970). Br. J. Pharmacol.120, 337-357.

Cao, W., Chen, Q., Sohn, U.D., Kim, N., Kirber, M.T., Harnett, K.M., Behar, J., and Biancani, P. (2001). $\mathrm{Ca}^{2+}$-induced contraction of cat esophageal circular smooth muscle cells. Am. J. Physiol. Cell. Physiol. 280, C980-992.

Chang, K., Hanaoka, K., Kumada, M., and Takuwa, Y. (1995). Molecular cloning and functional analysis of a novel P2 nucleotide receptor. J. Biol. Chem. 270, 26152-26158.

Cho, Y.R., Jang, H.S., Kim, W., Park, S.Y., and Sohn, U.D. (2010). P2X and P2Y receptors mediate contraction induced by electrical field stimulation in feline esophageal smooth muscle. Korean J. Physiol. Pharmacol. 14, 311-316.

Cowen, D.S., Sanders, M., and Dubyak, G. (1990). P2-purinergic receptors activate a guanine nucleotide-dependent phospholipase $\mathrm{C}$ in membranes from HL-60 cells. Biochim. Biophys. Acta 1053, 195-203.

Dubyak, G.R., and el-Moatassim, C. (1993). Signal transduction via P2-purinergic receptors for extracellular ATP and other nucleotides. Am. J. Physiol. 265, C577-606.

Fabiato, A and Fabiato, F. (1979). Calculator programs for computing the composition of the solutions containing multiple metals and ligands used for experiments in skinned muscle cells. J. Physiol. (Paris) 75, 463-505.

Fredholm, B.B., Abbracchio, M.P., Burnstock, G., Daly, J.W. Harden, T.K., Jacobson, K.A., Leff, P., and Williams, M. (1994) Nomenclature and classification of purinoceptors. Pharmacol. Rev. 46, 143-156.

Fredholm, B.B., Abbracchio, M.P., Burnstock, G., Dubyak, G.R. Harden, T.K., Jacobson, K.A., Schwabe, U., and Williams, M. (1997). Towards a revised nomenclature for $\mathrm{P} 1$ and $\mathrm{P} 2$ receptors. Trends Pharmacol. Sci. 18, 79-82.

Gilman, A.G. (1987). G proteins: transducers of receptor-generated signals. Annu. Rev. Biochem. 56, 615-649.

Haeberle, J.R., Hathaway, D.R., and DePaoli-Roach, A.A. (1985) Dephosphorylation of myosin by the catalytic subunit of a type-2 phosphatase produces relaxation of chemically skinned uterine smooth muscle. J. Biol. Chem. 260, 9965-9968.

Harden, T.K., Boyer, J.L., and Nicholas, R.A. (1995). P2-purinergic receptors: subtype-associated signaling responses and structure. Annu. Rev. Pharmacol.Toxicol. 35, 541-579.

Horowitz, A., Clement-Chomienne, O., Walsh, M.P., and Morgan, K.G. (1996). Epsilon-isoenzyme of protein kinase C induces a $\mathrm{Ca}(2+)$-independent contraction in vascular smooth muscle. Am. J. Physiol. 271, C589-594.

Huang, J., Zhou, H., Mahavadi, S., Sriwai, W., Lyall, V., and Murthy, K.S. (2005). Signaling pathways mediating gastrointestinal smooth muscle contraction and MLC20 phosphorylation by motilin receptors. Am. J. Physiol. Gastrointest. Liver Physiol. 288, G23-31.

ljzer, J., Kisjes, J.R., Penning, L.C., Rothuizen, J., and van, den, Ingh, T.S. (2009). The progenitor cell compartment in the feline liver: an (immuno)histochemical investigation. Vet. Pathol. 46, 614-621.

Ikebe, M., Hartshorne, D.J., and Elzinga, M. (1987). Phosphorylation of the 20,000-dalton light chain of smooth muscle myosin by the calcium-activated, phospholipid-dependent protein kinase. Phosphorylation sites and effects of phosphorylation. J. Biol. Chem. 262, 9569-9573.

Jiang, L.H., Kim, M., Spelta, V., Bo, X., Surprenant, A., and North, R.A. (2003). Subunit arrangement in P2X receptors. J. Neurosci. 23, 8903-8910.

Lazarowski, E.R., and Harden, T.K. (1994). Identification of a uridine nucleotide-selective G-protein-linked receptor that activates phospholipase-C. J. Biol. Chem. 269, 11830-11836.

Lechleiter, J., Hellmiss, R., Duerson, K., Ennulat, D., David, N., Clapham, D., and Peralta, E. (1990). Distinct sequence elements control the specificity of $G$ protein activation by muscarinic acetylcholine receptor subtypes. EMBO J. 13, 4381-4390.

Lee, H.Y., Bardini, M., and Burnstock, G. (2000). P2X receptor immunoreactivity in the male genital organs of the rat. Cell Tissue Res. 300, 321-330.
Lefebvre, R.A. (1993). Non-adrenergic non-cholinergic neurotransmission in the proximal stomach. Gen. Pharmac. 24, 257-266.

Lundberg, J.M. (1996). Pharmacology of cotransmission in the autonomic nervous system: integrative aspects on amines, neuropeptides, adenosine triphosphate, amino acids and nitric oxide. Pharmacol. Rev. 48, 113-178.

Matsuda, N.M., and Miller, S.M. (2010). Non-adrenergic noncholinergic inhibition of gastrointestinal smooth muscle and its intracellular mechanism(s). Fundam. Clin. Pharmacol. 24, 261268.

Murthy, K.S., McHenry, L., Grider, J.R., and Makhlouf, G.M. (1995). Adenosine $A 1$ and $A 2 b$ receptors coupled to distinct interactive signaling pathways in intestinal muscle cells. J. Pharmacol. Exp. Ther. 274, 300-306.

Murthy, K.S., and Makhlouf, G.M. (1998). Coexpression of ligandgated P2X and G protein-coupled P2Y receptors in smooth muscle. Preferential activation of P2Y receptors coupled to phospholipase C (PLC)-beta1 via Galphaq/11 and to PLC-beta3 via Gbetagammai3. J. Biol. Chem. 273, 4695-4704.

Murthy, K.S., Zhou, H., Grider, J.R., Brautigan, D.L., Eto, M., and Makhlouf, G.M. (2003). Differential signalling by muscarinic receptors in smooth muscle: $\mathrm{m} 2$-mediated inactivation of myosin light chain kinase via Gi3, Cdc42/Rac1 and p21-activated kinase 1 pathway, and m3-mediated MLC20 (20 kDa regulatory light chain of myosin II) phosphorylation via Rho-associated kinase /myosin phosphatase targeting subunit 1 and protein kinase C/CPI-17 pathway. Biochem. J. 374, 145-155.

Nam, Y.S., Suh, J.S. Song, H.J., and Sohn, U.D. (2013). Signaling pathway of lysophosphatidic Acid-induced contraction in feline esophageal smooth muscle cells. Korean J. Physiol. Pharmacol.17, 139-147.

Puetz, S., Lubomirov, L.T., and Pfitzer, G. (2009). Regulation of Smooth Muscle Contraction by Small GTPases. Physiology 24, 342-356.

Ralevic, V., and Burnstock, G. (1998). Receptors for purines and pyrimidines. Pharmacol. Rev. 50, 413-492.

Shim, J.O., Shin, C.Y., Lee, T.S., Yang, S.J., An, J.Y., Song, H.J. Kim, T.H., Huh, I.H., and Sohn, U.D. (2002). Signal transduction mechanism via adenosine $A 1$ receptor in the cat esophageal smooth muscle cells. Cell. Signal. 14, 365-372.

Sohn, U.D., Harnett, K.M., De Petris, G., Behar, J., and Biancani, P. (1993). Distinct muscarinic receptors, G proteins and phospholipases in esophageal and lower esophageal sphincter circular muscle. J. Pharmacol. Exp. Ther. 267, 1205-1214.

Sohn, U.D., Han, B., Tashjian, A.H., Jr., Behar, J., and Biancani, P. (1995a). Agonist-independent, muscle-type-specific signal-transduction pathways in cat esophageal and lower eso-phageal sphincter circular smooth-muscle. J. Pharmacol. Exp. Ther. 273, 482-491.

Sohn, U.D., Han, B., Tashijian, A.H., Jr., Behar, J., and Biancani, P (1995b). Agonist-independent, muscle-type-specific signal transduction pathways in cat esophageal and lower esophageal sphincter circular smooth muscle. J. Pharmacol Exp. Ther. 273, 482-491.

Sohn, U.D., Harnett, K.M., Cao, W., Rich, H., Kim, N., Behar, J., and Biancani, P. (1997). Acute experimental esophagitis activates a second signal transduction pathway in cat smooth muscle from the lower esophageal sphincter. J. Pharmacol. Exp. Ther. 283, 1293-1304.

Somlyo, A.P., and Somlyo, A.V. (1994). Signal transduction and regulation in smooth muscle. Nature 372, 231-236.

Surprenant, A. and North, R.A. (2009) Signaling at Purinergic P2X Receptors. Annu. Rev. Physiol. 71, 333-359.

van der Weyden, L., Conigrave, A.D., and Morris, M.B. (2000). Signal transduction and white cell maturation via extracellula ATP and the P2Y11 receptor. Immunol. Cell Biol. 78, 369-374.

Vantrappen, G., Janssens, J., Coremans, G. and Jian, R. (1986). Gastrointestinal motility disorders. Dig. Dis. Sci. 31, 5S-25S.

Webb, R.C. (2003). Smooth muscle contraction and relaxation. Adv. Physiol. Educ. 27, 201-206.

Yang, S.J., An, J.Y., Shim, J.O., Park, C.H., Huh, I.H., and Sohn, U.D. (2000). The mechanism of contraction by 2-chloroadenosine in cat detrusor muscle cells. J. Urol. 163, 652-658.

Yiangou, Y., Facer, P., Baecker, P.A., Ford, A.P., Knowles, C.H., Chan, C.L.H., Williams, N.S., and Anand, P. (2001). ATP-gated ion channel P2X(3) is increased in human inflammatory bowel disease. Neurogastroenterol. Motil. 13, 365-369. 